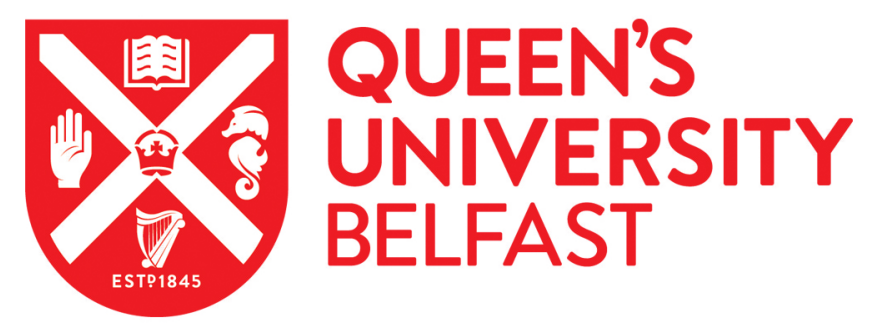

\title{
Antimicrobial Efficacy of an Innovative Emulsion of Medium Chain Triglycerides against Canine and Feline Periodontopathogens
}

\author{
Laverty, G., Gilmore, B. F., Jones, D. S., Coyle, L., Folan, M., \& Breathnach, R. (2015). Antimicrobial Efficacy of \\ an Innovative Emulsion of Medium Chain Triglycerides against Canine and Feline Periodontopathogens. Journal \\ of Small Animal Practice, 56(4), 253-263. https://doi.org/10.1111/jsap.12344
}

Published in:

Journal of Small Animal Practice

\section{Document Version:}

Peer reviewed version

Queen's University Belfast - Research Portal:

Link to publication record in Queen's University Belfast Research Portal

\footnotetext{
Publisher rights

(c) 2015 British Small Animal Veterinary Association

This is the peer reviewed version of the following article: Laverty, G., Gilmore, B. F., Jones, D. S., Coyle, L., Folan, M. and Breathnach, R. (2015), Antimicrobial efficacy of an innovative emulsion of medium chain triglycerides against canine and feline periodontopathogens. Journal of Small Animal Practice, 56: 253-263., which has been published in final form at

http://onlinelibrary.wiley.com/doi/10.1111/jsap.12344/abstract This article may be used for non-commercial purposes in accordance with Wiley Terms and Conditions for Self-Archiving."

General rights

Copyright for the publications made accessible via the Queen's University Belfast Research Portal is retained by the author(s) and / or other copyright owners and it is a condition of accessing these publications that users recognise and abide by the legal requirements associated with these rights.
}

Take down policy

The Research Portal is Queen's institutional repository that provides access to Queen's research output. Every effort has been made to ensure that content in the Research Portal does not infringe any person's rights, or applicable UK laws. If you discover content in the Research Portal that you believe breaches copyright or violates any law, please contact openaccess@qub.ac.uk. 
1 Antimicrobial Efficacy of an Innovative Emulsion of Medium Chain Triglycerides against

2 Canine and Feline Periodontopathogens

3

4 G. Laverty ${ }^{1,2 *}$, B.F. Gilmore ${ }^{2}$, D.S. Jones ${ }^{2}$, L.Coyle ${ }^{1}$, M.Folan ${ }^{3}$, R.Breathnach ${ }^{3}$.

$5 \quad{ }^{1}$ Ward Research \& Development Ltd., Glasdrumman, Milltown, Monaghan, Ireland.

$6 \quad{ }^{2}$ Biomaterials, Biofilm and Infection Control Research Group, School of Pharmacy, Queens

7 University Belfast, 97 Lisburn Road, Belfast, BT9 7BL, UK.

$8 \quad{ }^{3}$ UCD Veterinary Sciences Centre, University College Dublin, Belfield, Dublin 4, Ireland

9

$10 *$ Corresponding author. Tel.: +44 2890972273

11 Email address: garry.laverty@qub.ac.uk

Conflict of interest statement

G. Laverty was supported by an InterTradeIreland Fusion grant supporting collaborative research between Ward Research \& Development Ltd and Queen's University Belfast; L. Coyle is an employee of Ward Research \& Development Ltd and R. Breathnach, B. Gilmore and D.Jones have acted as consultants to Ward Research \& Development Ltd.

Acknowledgements

The authors would like to acknowledge Prof. Alan Baird, School of Veterinary Medicine, Veterinary Sciences Centre, University College Dublin for his helpful comments on the scientific aspects of this manuscript. 
To test the in vitro antimicrobial efficacy of a non-toxic emulsion of free fatty acids against clinically relevant canine and feline periodontopathogens for the prevention of periodontitis and gingivitis in cats and dogs.

Methods

Antimicrobial kill kinetics were established utilising an alamarBlue ${ }^{\circledR}$ viability assay against ten strains of canine and feline periodontopathogens, in the biofilm mode of growth, at a concentration of $0.125 \%$ $\mathrm{v} / \mathrm{v}$ medium chain triglyceride (ML:8) emulsion. The results were compared with $0.12 \% \mathrm{v} / \mathrm{v}$ chlorhexidine digluconate and a commercially available xylitol-containing dental formulation (Virbac Vet Aquadent $\left.{ }^{\circledR}\right)$. Mammalian cellular cytotoxicity was also investigated for both the ML:8 emulsion and chlorhexidine digluconate $(0.25$ to $0.0625 \% \mathrm{v} / \mathrm{v})$ using in vitro tissue culture techniques. Results

No statistically significant difference was observed in the antimicrobial activity of $0.125 \% \mathrm{v} / \mathrm{v}$ ML:8 emulsion and $0.12 \% \mathrm{v} / \mathrm{v}$ chlorhexidine digluconate against all ten periodontopathogens tested; a high percentage kill rate (> 70\%) was achieved within 5 minutes of exposure and at subsequent time points investigated. A statistically significant improvement in antibiofilm activity was seen with $0.125 \% \mathrm{v} / \mathrm{v}$ ML:8 emulsion when compared with a currently available xylitol containing drinking water additive (Virbac Vet Aquadent $\left.{ }^{\circledR}\right)$. The ML:8 emulsion possessed a significantly lower $(\mathrm{P}<0.001)$ toxicity profile when compared to $0.12 \% \mathrm{v} / \mathrm{v}$ chlorhexidine digluconate in cytotoxicity assays.

\section{Clinical Significance}

The ML:8 emulsion exhibited significant potential as a putative effective antimicrobial alternative to chlorhexidine- and xylitol- based products for the prevention of periodontal disease, which, when compared to chlorhexidine at equivalent concentration, exhibited significantly reduced cytotoxic characteristics.

Keywords: Periodontitis, antimicrobial, medium chain triglycerides, biofilm bacteria, fatty acids. 
Periodontitis is the most common described progressive inflammatory disease in companion animal practice, affecting more than 80-85\% of dogs and cats above three years of age (Watson 2006). Within the oral cavity, the condition refers to inflammation of the tooth support structures leading to damage and loss of the periodontal membrane, alveolar bone and adjacent soft tissues; the resulting damage may potentially result in tooth loss. The severity and prognosis of dental disease is dependent on multiple factors including species, age, breed, genetics, nutritional status, the presence of irritants, chewing activity, co-morbidities, dental crowding, occlusion and oral microbial profile (Harvey and Emily 1993). The prospect for systemic and chronic diseases to develop subsequent to periodontal disease is high due to the dense vascular network of the gum tissue (DeBowes et al. 1996).

The tooth and its supporting structures provide an optimum environment for the growth and replication of transient microorganisms within the mouth (Wiggs and Lobprise 1997). Food particles collect between the teeth to provide a nutrient source for the development of a bacterial biofilm community (plaque) at the tooth's surface. Bacteria, growing as biofilms, are notoriously difficult to eradicate, often requiring bactericidal concentrations of 10-1000 times that of free-floating, planktonic bacteria in suspension. Exposure to sub-optimal or sub-therapeutic antimicrobial concentrations in the biofilm thereby increases the potential for antimicrobial resistance development (Stewart and Costerton 2001). Within days minerals in the saliva, such as calcium, combine with plaque to form calculus material (tartar) and an immune response is initiated by the host resulting in the inflammatory signs of gingivitis and periodontitis, indirect periodontal destruction, pain, halitosis and loss of appetite (Wiggs and Lobprise 1997). The microbial ecology of the oral cavity of cats and dogs is vastly diverse with aerobic bacteria predominating in the early phase of gingivitis, followed by a predominantly anaerobic and Gramnegative bacterial profile when periodontitis becomes established (Hennet and Harvey 1991) (Harvey et al. 1995). The process of bacterial biofilm formation begins on the tooth surface immediately after successful scaling. Initially, Gram-positive cocci, including Streptococci (Leonhardt et al. 1992) 
(Radice et al. 2006) become attached to the surface. Further growth and maturation of this aerobic or facultative flora leads to depletion of locally available oxygen and anaerobes such as Porphyromonas gingivalis and Fusobacterium nucleatum become more predominant (Cleland 2001). As gingival inflammation develops in response to the presence of bacteria, metabolic and inflammatory products such as endotoxins become constitute major components of the gingival fluid, contributing to local oral and systemic tissue destruction and dental bone loss (Holmstrom and others 2004). Invasive pathogens capable of active spread through the systemic blood supply may colonise other highly vascularised tissues including the kidneys, liver and heart. These micro-abscesses reduce overall longterm health for the animal, increasing risk factors associated with heart disease, hypertension and kidney disease (Glickman et al. 2011).

For both cats and dogs, treatment of established infection centres on the use of antibiotics and antiinflammatory agents, along with dental scaling and polishing (physical removal of calculus) performed by a veterinary practitioner. Scaling and removal of subgingival plaque is particularly problematic, often requiring administration of a general anaesthetic with the procedure repeated regularly throughout the animal's lifetime (Harvey 2005). Preventative therapy is typically centred on mechanical removal of adhered bacteria with a routine of regular toothbrushing aided by veterinary toothpastes containing antimicrobials ranging from chlorhexidine digluconate and cetylpyridium chloride to enzyme-based formulations. However, in addition to pet compliance issues, the effective removal of plaque requires the pet owner to be manually dexterous and patient (Iacono et al. 1998). In real-life practice, these factors often limit successful compliance.

This study describes the formulation of an antimicrobial emulsion, intended for buccal application in companion animals, comprising of a medium chain triglyceride (ML:8) oil phase dispersed in water that displays in vitro efficacy at a low concentration $(0.125 \% \mathrm{v} / \mathrm{v})$ against resistant biofilm forms of ten periodontopathogens clinically implicated in canine and feline dental disease (Elliot et al. 2005) (Kolenbrander et al. 2002). This antimicrobial emulsion has the potential to be utilised as a drinking water additive to increase ease of use for the pet owner and subsequent aid compliance, with the 
overall aims of reducing long-term oral bacterial bioburden and the incidence of periodontal disease in

114 both cats and dogs.

Materials and Methods

\section{Formulation of ML:8 Emulsion}

118 The antimicrobial composition of ML:8 consists of an oil in water emulsion. A mixture of free fatty

119 acids solubilised in water is promoted by the addition of membrane lipids, in this case lecithin. Lower

120 melting point fatty acids such as caprylic and oleic acid were utilised to a final concentration of

$1216.375 \% \mathrm{w} / \mathrm{w}$. The ratio of free fatty acids to membrane lipid was 1.275:1. The final formulation was

122 freshly diluted 1 in 51 (0.125\% v/v free fatty acids) in sterile water before analysis.

\section{Comparator Substances}

125 Chlorhexidine digluconate was obtained from Sigma-Aldrich (Dorset, UK). A commercially available

126 drinking water additive (Virbac Vet Aquadent ${ }^{\circledR}$ ) containing xylitol 0.5\% concentration (with

127 chlorhexidine $<0.01 \%$ ) was obtained from Virbac (Bury St Edmonds, UK).

\section{Microbial Isolates Investigated}

Haemophilus actinomycetemcomitans (NCTC 10979), Streptococcus sanguinis (NCTC 10904) were obtained from HPA Culture Collections (Salisbury, UK). Porphyromonas cangingivalis (VPB 4874), Porphyromonas salivosa (VPB 3313), Porphyromonas gingivalis (VPB 5089), Fusobacterium nucleatum (VPB 4888), Eikenella corrodens (VPB 3935), Bacteroides fragilis (VPB 3371), Prevotella intermedia (VPB 3321) and Tanerrella forsythesis (VPB 4947) were obtained from Dr Denise microorganisms were stored at $-80^{\circ} \mathrm{C}$ in $10 \%$ glycerol.

139 Microorganisms under investigation were grown over $48-72$ hours at $37^{\circ} \mathrm{C}$ in Tryptone Soya broth in a

140 Biomat Class II Microbiological anaerobic Safety Cabinet (Don Whitely Scientific Ltd., Shipley, UK). 
141 Upon visual confirmation of growth, the inoculum and adjusted to an optical density of 0.3 at $550 \mathrm{~nm}$

142 in QSRS solution, which was equivalent to $1 \times 10^{8}$ colony forming units per milliliter (CFU/mL). This

143 suspension was further diluted in Tryptone Soya broth (TSB) (1 in 50) and dispensed aseptically in

$144100 \mu \mathrm{L}$ aliquots to each well of the microtitre plate. The inoculated plates were placed in Anaerogen

145 sachets (Oxoid, Hampshire, UK) and the air tight sachets containing the inoculated plates were

146 removed from the cabinet and biofilm were formed on the surface of the well under shear stress

147 provided by a Gallenkamp gyrorotary incubator at $37^{\circ} \mathrm{C}$. After an inoculation period of 48 hours, the

148 Anaerogen sachets containing the biofilm growth plates were transferred to the anaerobic cabinet,

149 cultures were decanted and the plates irrigated twice with $200 \mu \mathrm{L}$ of sterile autoclaved $0.9 \% \mathrm{w} / \mathrm{v}$

150 sodium chloride $(\mathrm{NaCl})$ in each well. Washed plates were tapped gently upside down on a sterile

151 paper towel to remove residual wash. The prepared biofilm was treated for evaluation of viability

152 using alamarBlue ${ }^{\circledR}$ in a method similar to that used by Pettit et al. (2005). The viability of established

153 biofilms was assessed by re-charging wells from above immediately after washing and without drying,

154 with $0.1 \mathrm{~mL}$ fresh TSB broth containing 20\% v/v alamarBlue ${ }^{\circledR}$ (AbD Serotec, Oxford, UK), incubating

155 the plate at $37^{\circ} \mathrm{C}$ for one hour followed by spectrophotometric measurement of absorbance at a

156 wavelength of $570 \mathrm{~nm}$. AlamarBlue ${ }^{\circledR}$ is resazurin, a redox indicator which is reduced by metabolic

157 activity of viable microbial cells to pink fluorescent resorfurin. The reduction of viability (killing) of

158 established biofilm with the test formulations was evaluated by loading wells containing washed

159 biofilm from above immediately after washing with $0.1 \mathrm{~mL}$ of $0.125 \% \mathrm{v} / \mathrm{v}$ ML:8 emulsion, 0.12\% v/v

160 chlorhexidine digluconate or xylitol followed by incubation at $37^{\circ} \mathrm{C}$. Time points selected for analysis

161 of ML:8 emulsion/chlorhexidine digluconate/xylitol activity on established biofilms were 0, 5, 10, 20,

16230 , 40, 50 and 60 minutes, followed by 2, 4 and 24 hours. Each control well had 8 replicates at each

163 time point. Blank determinations (100\% viability: positive control) were conducted using sterile

164 distilled water. Immediately following incubation, the exposed biofilms were washed twice by

165 irrigation with sterile $0.9 \% \mathrm{w} / \mathrm{v} \mathrm{NaCl}$ and recharged with fresh TSB containing $20 \% \mathrm{v} / \mathrm{v}$ alamarBlue ${ }^{\circledR}$

166 (sterilized by passage twice through a syringe fitted with a $0.22 \mu \mathrm{m}$ membrane filter) and $3 \% \mathrm{w} / \mathrm{v}$

167 Tween 80 (polysorbate), incubated at $37^{\circ} \mathrm{C}$ for 1 hour and the development of UV absorbance was then

168 measured spectrophotometrically at 570nm. A positive control (100\% microbicidal effect) was also 
included in the assay using 2\% chlorhexidine digluconate. Reduction in viability of biofilm following exposure to the test formulations was expressed as a percentage based on the percentage reduction between untreated (blank) wells and treated wells using the following equation:

$\%$ reduction in viability $\equiv \frac{\text { Abs570nm } M L: 8 \text { Emulsion/Chlorhexidine digluconate / Virbac Vet Aquadent }{ }^{\circledR}-\text { Abs570nm Blank }}{\text { Abs570nm Chlorhexidine digluconate } 2 \%-\text { Abs570nm Blank }} \times 100$

\section{Cell Survival Analysis (cytotoxicity assays)}

176 Two individual mammalian cell lines were selected for cytotoxicity analysis following exposure to the 177 test formulations. These were Het-1A (ATCC CRL-2692) human oesophageal cells and NCTC Clone 929 (ATCC CCL 1) murine fibroblast subcutaneous connective tissue cells; areolar and adipose International Standard cell lines. Both cell lines were obtained from LGC Standards (London, UK). NCTC Clone 929 (ATCC CCL 1) cell line was cultured in Minimum Essential Medium (MEM) containing phenol red with Earle’s Salts, L-Glutamine, supplemented with 10\% Horse Serum,100iu/mL penicillin and $100 \mu \mathrm{g} / \mathrm{mL}$ streptomycin supplied by Invitrogen (Paisley, UK). The

183 Het-1A (ATCC CRL-2692) cell line was cultured in Bronchial Epithelial cell Basal Medium (BEBM)

184 supplemented by Bronchial Epithelial Cell Growth Medium (BEGM) SingleQuot Kit and Growth Factors (Lonza, Basle, Switzerland). Cells were grown at $37^{\circ} \mathrm{C}$ and $5 \% \mathrm{CO}_{2}$ and subcultured at 80 $90 \%$ confluency. Subculturing consisted of removal of spent medium, rinsing of the adherent cell surface with sterile autoclaved phosphate buffered saline (PBS) before treatment with a $0.05 \%$

188 Trypsin/0.53mM EDTA•4Na solution (Invitrogen, Paisley, UK) for cell monolayer detachment. For 189 the Het-1A (ATCC CRL-2692) cell line Trypsin/EDTA required inclusion of 0.5\%

190 polyvinylpyrrolidone (Sigma-Aldrich, Dorset, UK) and preparation flasks were required to be 191 precoated with $0.01 \mathrm{mg} / \mathrm{mL}$ fibronectin, $0.03 \mathrm{mg} / \mathrm{mL}$ bovine collagen type I and $0.01 \mathrm{mg} / \mathrm{mL}$ bovine serum albumin (all supplied by Invitrogen, Paisley, UK) to facilitate attachment.

194 Cell viability was assessed by means of a quantitative alamarBlue ${ }^{\circledR}$ assay, using a modification of the 195 method of O'Brien et al. (2000). Cells were cultured (until at least third passage) and inoculated into 196 96-well tissue culture treated microtitre plates at a concentration of $1 \times 10^{4}$ cells/well and incubated at 
$37^{\circ} \mathrm{C}$ and $5 \% \mathrm{CO}_{2}$ for $24 \pm 1$ hour, until approximately $90 \%$ confluency as described above. After this

198 time, the medium was removed and replaced with required fresh growth medium, containing doubling

199 dilutions of ML:8 emulsion at final concentrations of $0.25-0.0625 \% \mathrm{v} / \mathrm{v}$ with eight replicates at each

200 concentration. Chlorhexidine digluconate was tested over the same concentration range and acted as a

201 comparative control. Time points selected for analysis of ML:8 emulsion/chlorhexidine digluconate

202 activity on established cell lines were 5, 30 and 60 minutes. Absorption was measured at 570nm in a

203 Tecan Sunrise ${ }^{\circledR}$ plate reader after a development time of 10 hours for NCTC Clone 929 (ATCC CCL

204 1) cell line and 4 hours for Het-1A (ATCC CRL-2692) cell line. A positive control (100\% reduction

205 in viability) was also included in the assay using 90\% ethanol (Sigma-Aldrich, Dorset, UK); the

206 negative control consisted of untreated cell line wells percentage cell viability was calculated relative

207 to untreated control wells after subtraction of the blank value corresponding to untreated cells in the

208 absence of alamarBlue ${ }^{\circledR}$ reagent.

209

$\%$ reduction in viability $\equiv \frac{A b s_{570 n m} M L: 8 \text { Emulsion /Chlorhexidine digluconate }- \text { Abs570nm Blank }}{A b s_{570 n m} \text { ethanol } 90 \%-A b s_{570 n m} \text { Blank }} \times 100$

\section{Statistical Analysis}

213 Statistical analyses were performed using GraphPad InStat 3. Standard deviations were obtained at

214 each concentration/timepoint of antimicrobials tested based on eight replicates for both quantitative

215 biofilm and cell cytotoxicity viability assays and mean values obtained. Further statistical analysis

216 was employed using a one way Analysis of Variance (ANOVA), with a Tukey-Kramer multiple

217 comparisons test used to identify individual differences between the antibiofilm activity of $0.125 \% \mathrm{v} / \mathrm{v}$

218 ML:8 emulsion and $0.12 \%$ v/v chlorhexidine digluconate, and also the antibiofilm activity of $0.125 \%$

219 v/v ML:8 emulsion and 2.4\% v/v Virbac Vet Aquadent ${ }^{\circledR}$ (as directed by the manufacturer), at relative

220 timepoints. ANOVA with a Tukey-Kramer multiple comparisons test was also utilised for statistical

221 analysis of cytotoxicity data of ML:8 emulsion and chlorhexidine digluconate at the same

222 concentrations $(0.25-0.06125 \% \mathrm{v} / \mathrm{v})$ and relative timepoints. ANOVA assumes that the data is

223 sampled from populations that follow Gaussian distributions. Data was shown to be normally 
224 distributed using the Kolmogorov and Smirnov method. In all cases a probability of $\mathrm{P} \leq 0.05$ denoted 225 significance.

Results

The $0.125 \% \mathrm{v} / \mathrm{v}$ ML:8 emulsion displayed significant activity against biofilm forms of the 10 periodontopathogens investigated within 5 to 10 minutes exposure. Antibiofilm efficacy was significantly greater than the $2.4 \% \mathrm{v} / \mathrm{v}$ Virbac Vet Aquadent ${ }^{\circledR}$ (xylitol containing formulation) and statistically similar to $0.12 \% \mathrm{v} / \mathrm{v}$ chlorhexidine digluconate. Antibiofilm activity for $0.125 \% \mathrm{v} / \mathrm{v}$ ML:8 emulsion, $0.12 \% \mathrm{v} / \mathrm{v}$ chlorhexidine digluconate and xylitol containing formulation are displayed in Figures 1-10. ML:8 emulsion was significantly less cytotoxic than chlorhexidine digluconate at similar concentrations ( $\mathrm{P}<0.001$ for all assays). Cytotoxicity of ML:8 emulsion and chlorhexidine digluconate at the same concentrations $(0.25-0.06125 \%$ v/v) against CCL 1 (NCTC Clone 929) murine fibroblast subcutaneous connective tissue monolayer cells and human oesophageal tissue monolayer cells (ATCC CRL-2692) are shown in Figures 11 and 12, respectively.

\section{Discussion}

240 The results of the current study demonstrate that ML:8 emulsion displayed a high degree of potency 241 against 48 hour biofilm forms of the 10 periodontopathogens investigated. High percentage kill rates 242 (> 70\%) were achieved against the majority of test organisms within 5 minutes of exposure, and at all 243 subsequent time points. The selection of biofilm forms of bacteria was purposeful in order to test the 244 ability of the formulation to eradicate this more resistant bacterial phenotype present within the oral 245 cavity (Hojo et al. 2009). The majority of previously reported dental-related studies have centred on 246 human plaque and less resistant liquid planktonic forms of bacteria (Stanley et al. 1989) (McBain et al. 2004), and whilst contributing valuable information, their clinical relevance may be limited in

248 comparison to biofilm-based data. The bacteria selected for assessment in the current study were

249 derived from an extensive literature search for relevant canine and feline periodontopathogens, and as 250 such, have direct relevance to the clinical microbiota encountered in canine/feline periodontal disease 
251 (Syed and Svanberg 1981)(Svanberg et al. 1982)(Hennet and Harvey 1991)(Leonhardt et al.

252 1992)(Okuda and Harvey 1992)(Harvey et al. 1995)(Harvey 1998)(Harvey 2005).

253

254 The antimicrobial activity of free fatty acids has been widely reported previously in the literature

255 (Kabara et al. 1972). Research conducted by Sun et al. (2002) concluded that caprylic $\left(\mathrm{C}_{8}\right)$, capric

$256 \quad\left(\mathrm{C}_{10}\right)$ and lauric acid $\left(\mathrm{C}_{12}\right)$ displayed antimicrobial activity with lauric and caprylic acid shown to be

257 most efficacious against Gram-positive and Gram-negative bacteria, respectively. The ML:8 emulsion

258 formulation described here displayed rapid antimicrobial efficacy, showing high potential to be an

259 effective drinking water additive for periodontal disease prevention at low concentrations $(0.125 \%$

$260 \mathrm{v} / \mathrm{v}$ ), despite the limited exposure times that can be achieved within the oral cavity. To test this

261 hypothesis further, we compared the anti-biofilm activity of the ML:8 emulsion with the gold standard

262 in human/veterinary dental hygiene ( $0.12 \%$ chlorhexidine digluconate) and another commercially

263 available veterinary dental formulation containing 0.5\% xylitol (prediluted). With the exception of the

2640 minute timepoints for Porphyromonas gingivalis (VPB 5089), Eikenella corrodens (VPB 3935) and

265 Tanerrella forsythensis (VPB 4947), there was no significant difference in the antibiofilm activity of

$2660.125 \%$ v/v ML:8 emulsion and 0.12\% v/v chlorhexidine digluconate $(\mathrm{P}>0.05)$. However, although

267 chlorhexidine has been a mainstay in the control and treatment of dental pathogens in human health

268 (Roberts et al. 2002), similar effective concentrations cannot be employed in canine drinking water

269 formulations as the ingestion/swallowing of solutions containing $0.12 \% \mathrm{v} / \mathrm{v}$ chlorhexidine on a daily

270 basis is likely to be associated with significant cytotoxicity, as demonstrated by the results generated

271 in this study (see later). At concentrations significantly below the traditional $0.12 \% \mathrm{v} / \mathrm{v}$ threshold

272 employed in human products, the range of chlorhexidine-based drinking water additives available on

273 the veterinary market have debatable in vitro and in vivo efficacy (Roudebush et al. 2005).

274

275 Virbac Vet Aquadent ${ }^{\circledR}$ contains xylitol and $<0.05 \%$ chlorhexidine digluconate (the chlorhexidine

276 component is not included as an active ingredient). Our results show Aquadent ${ }^{\circledR}$ to have limited

277 efficacy against biofilm forms of periodontal bacteria tested up to 24 hours under the conditions of this

278 assay. At the 24 hour timepoint, the reduction in viable biofilm reached a maximum of 53\% against 

reduction of biofilm of less than 10\%. Overall, the $0.125 \%$ v/v ML:8 emulsion showed a statistically significant increase in biofilm reduction when compared with Aquadent ${ }^{\circledR}$ in $93.6 \%$ of the comparative time points/bacteria tested (103 out of 110 sample points; $\mathrm{P}<0.001$ ). Although issues have been raised in relation to the potential toxic effects of xylitol ingestion in dogs (Murphy et al. 2012), the dose levels employed in Aquadent ${ }^{\circledR}$ have not been associated with any reported toxic effects in the published literature.

Figures 11 and 12 show that at therapeutic concentrations $(0.12 \% \mathrm{v} / \mathrm{v})$ chlorhexidine digluconate demonstrated toxicity against mammalian cell lines; therefore, its long-term use or suitability as a drinking water additive may be limited by potential gastrointestinal and oral mucosal damage. At the same concentrations and correlating to the same exposure times and cell lines, the toxicity demonstrated by ML:8 emulsion was significantly lower $(\mathrm{P}<0.001)$ than for chlorhexidine digluconate. After up to 60 minutes exposure to varying concentrations of ML:8 emulsion ( 0.25 to $0.0625 \% \mathrm{v} / \mathrm{v}$ ), the relative percentage kill of CCL 1 (NCTC Clone 929) murine fibroblast cells was absent (0\%). The results obtained for chlorhexidine digluconate against both human oesophageal tissue (ATCC CRL-2692) and the International cytotoxicity standard CCL 1 (NCTC Clone 929) murine fibroblast cells showed a statistically significant increase $(\mathrm{P}<0.001)$ in the cytotoxic activity of chlorhexidine digluconate relative to ML:8 at all time points studied. Quantitative evaluations such as the alamarBlue ${ }^{\circledR}$ assay determine that a reduction of cell viability by more than $30 \%$ is indicative of cytotoxicity (International Standard ISO10993-5). Selection of the International cytotoxicity standard CCL 1 (NCTC Clone 929) murine fibroblast cell line allowed this novel formulation to be assessed for cytotoxicity in general, whilst selection of a mammalian oesophageal cell line also allowed the toxicity of ML:8 to be compared to a clinically relevant cell line.

\section{Conclusions}


v/v final concentration. Such a product can increase compliance and ease of use allowing daily

administration to help prevent periodontal disease, with superior in vitro results compared with a

currently available xylitol-based drinking water additive. The findings of this study validate the use of the ML:8 emulsion as part of an ever increasing evidence-based approach to biofilm control in veterinary dental applications (Hamp and others 1973). Although in vivo clinical trials are now indicated to corroborate these findings, our initial laboratory results show large scope and promise for continuing research in this area.

\section{References}

Cleland, W.P., Jr 2001, "Opportunities and obstacles in veterinary dental drug delivery", Advanced Drug Delivery Reviews, vol. 50, no. 3, pp. 261-275.

DeBowes, L.J., Mosier, D., Logan, E., Harvey, C.E., Lowry, S. \& Richardson, D.C. 1996, "Association of periodontal disease and histologic lesions in multiple organs from 45 dogs", Journal of veterinary dentistry, vol. 13, no. 2, pp. 57-60.

Elliott, D.R., Wilson, M., Buckley, C.M. \& Spratt, D.A. 2005, "Cultivable oral microbiota of domestic dogs", Journal of clinical microbiology, vol. 43, no. 11, pp. 5470-5476.

Gervas, J., Starfield, B. \& Heath, I. 2008, "Is clinical prevention better than cure?" Lancet, vol. 372, no. 9654, pp. 1997-1999.

Glickman, L.T., Glickman, N.W., Moore, G.E., Goldstein, G.S. \& Lewis, H.B. 2009, "Evaluation of the risk of endocarditis and other cardiovascular events on the basis of the severity of periodontal

Glickman, L.T., Glickman, N.W., Moore, G.E., Lund, E.M., Lantz, G.C. \& Pressler, B.M. 2011, "Association between chronic azotemic kidney disease and the severity of periodontal disease in dogs", Preventive veterinary medicine, vol. 99, no. 2-4, pp. 193-200. 
Harvey, C.E. 2005, "Management of periodontal disease: understanding the options", The Veterinary clinics of North America.Small animal practice, vol. 35, no. 4, pp. 819-36, vi.

Harvey, C.E. 1998, "Periodontal disease in dogs. Etiopathogenesis, prevalence, and significance", The Veterinary clinics of North America.Small animal practice, vol. 28, no. 5, pp. 1111-28, vi.

Harvey, C.E. \& Emily, P.P. 1993, "Periodontal disease" in Small Animal Dentistry, eds. C.E. Harvey \& P.P. Emily, pp. 89-144.

Harvey, C.E., Thornsberry, C. \& Miller, B.R. 1995, "Subgingival bacteria--comparison of culture results in dogs and cats with gingivitis", Journal of veterinary dentistry, vol. 12, no. 4, pp. 147150.

Hennet, P.R. \& Harvey, C.E. 1991, "Anaerobes in periodontal disease in the dog: a review", Journal of veterinary dentistry, vol. 8, no. 2, pp. 18-21.

Hojo, K., Nagaoka, S., Ohshima, T. \& Maeda, N. 2009, "Bacterial interactions in dental biofilm development", Journal of dental research, vol. 88, no. 11, pp. 982-990.

Holmstrom, S.E., Frost-Fitch, P. \& Eisner, E.R. 2004, Veterinary Dental Techniques for the Small Animal Practitioner, 3rd ed edn, Saunders, Philadelphia.

Iacono, V.J., Aldredge, W.A., Lucks, H. \& Schwartzstein, S. 1998, "Modern supragingival plaque control", International dental journal, vol. 48, no. 3 Suppl 1, pp. 290-297.

Kabara, J.J., Swieczkowski, D.M., Conley, A.J. \& Truant, J.P. 1972, "Fatty acids and derivatives as antimicrobial agents", Antimicrobial Agents and Chemotherapy, vol. 2, no. 1, pp. 23-28.

Kolenbrander, P.E., Andersen, R.N., Blehert, D.S., Egland, P.G., Foster, J.S. \& Palmer, R.J., Jr 2002, "Communication among oral bacteria", Microbiology and molecular biology reviews: MMBR, vol. 66, no. 3, pp. 486-505.

Leonhardt, A., Berglundh, T., Ericsson, I. \& Dahlen, G. 1992, "Putative periodontal pathogens on titanium implants and teeth in experimental gingivitis and periodontitis in beagle dogs", Clinical oral implants research, vol. 3, no. 3, pp. 112-119.

McBain, A.J., Ledder, R.G., Sreenivasan, P. \& Gilbert, P. 2004, "Selection for high-level resistance by chronic triclosan exposure is not universal", The Journal of antimicrobial chemotherapy, vol. 53, no. 5, pp. $772-777$. 
Murphy, L.A. \& Coleman, A.E. 2012, "Xylitol toxicosis in dogs", The Veterinary clinics of North America.Small animal practice, vol. 42, no. 2, pp. 307-12, vii.

O'Brien, J., Wilson, I., Orton, T. \& Pognan, F. 2000, "Investigation of the Alamar Blue (resazurin) fluorescent dye for the assessment of mammalian cell cytotoxicity", European journal of biochemistry/ FEBS, vol. 267, no. 17, pp. 5421-5426.

Okuda, A. \& Harvey, C.E. 1992, "Etiopathogenesis of feline dental resorptive lesions", The Veterinary clinics of North America.Small animal practice, vol. 22, no. 6, pp. 1385-1404.

Pettit, R.K., Weber, C.A., Kean, M.J., Hoffmann, H., Pettit, G.R., Tan, R., Franks, K.S. \& Horton, M.L. 2005, "Microplate Alamar blue assay for Staphylococcus epidermidis biofilm susceptibility testing", Antimicrobial Agents and Chemotherapy, vol. 49, no. 7, pp. 2612-2617.

Radice, M., Martino, P.A. \& Reiter, A.M. 2006, "Evaluation of subgingival bacteria in the dog and susceptibility to commonly used antibiotics", Journal of veterinary dentistry, vol. 23, no. 4, pp. 219-224.

Roberts, S.K., Wei, G.X. \& Wu, C.D. 2002, "Evaluating biofilm growth of two oral pathogens", Letters in applied microbiology, vol. 35, no. 6, pp. 552-556.

Roudebush, P., Logan, E. \& Hale, F.A. 2005, "Evidence-based veterinary dentistry: a systematic review of homecare for prevention of periodontal disease in dogs and cats", Journal of veterinary dentistry, vol. 22, no. 1, pp. 6-15.

Stanley, A., Wilson, M. \& Newman, H.N. 1989, "The in vitro effects of chlorhexidine on subgingival plaque bacteria", Journal of clinical periodontology, vol. 16, no. 4, pp. 259-264.

Stewart, P.S. \& Costerton, J.W. 2001, "Antibiotic resistance of bacteria in biofilms", Lancet, vol. 358, no. 9276, pp. 135-138.

Sun, C.Q., O'Connor, C.J. \& Roberton, A.M. 2002, "The antimicrobial properties of milkfat after partial hydrolysis by calf pregastric lipase", Chemico-biological interactions, vol. 140, no. 2, pp. 185-198.

Svanberg, G.K., Syed, S.A. \& Scott, B.W., Jr 1982, "Differences between gingivitis and periodontitis associated microbial flora in the beagle dog. Relationship of plaque parameters to histological parameters of periodontal disease", Journal of periodontal research, vol. 17, no. 1, pp. 1-11. 
Syed, S.A., Svanberg, M. \& Svanberg, G. 1981, "The predominant cultivable dental plaque flora of beagle dogs with periodontitis", Journal of clinical periodontology, vol. 8, no. 1, pp. 45-56.

392

393

Watson, A.D.J. 2006, "Diet and Periodontal Disease in Dogs and Cats", Aust Vet J, vol. 71, pp. 313318.

Wiggs, R.B. \& Lobprise, H.B. 1997, "Periodontology" in Veterinary Dentistry Principles and Practice, eds. R.B. Wiggs \& H.B. Lobprise, Lippincott-Raven, Philadelphia, pp. 186-231.

Figure/Legends

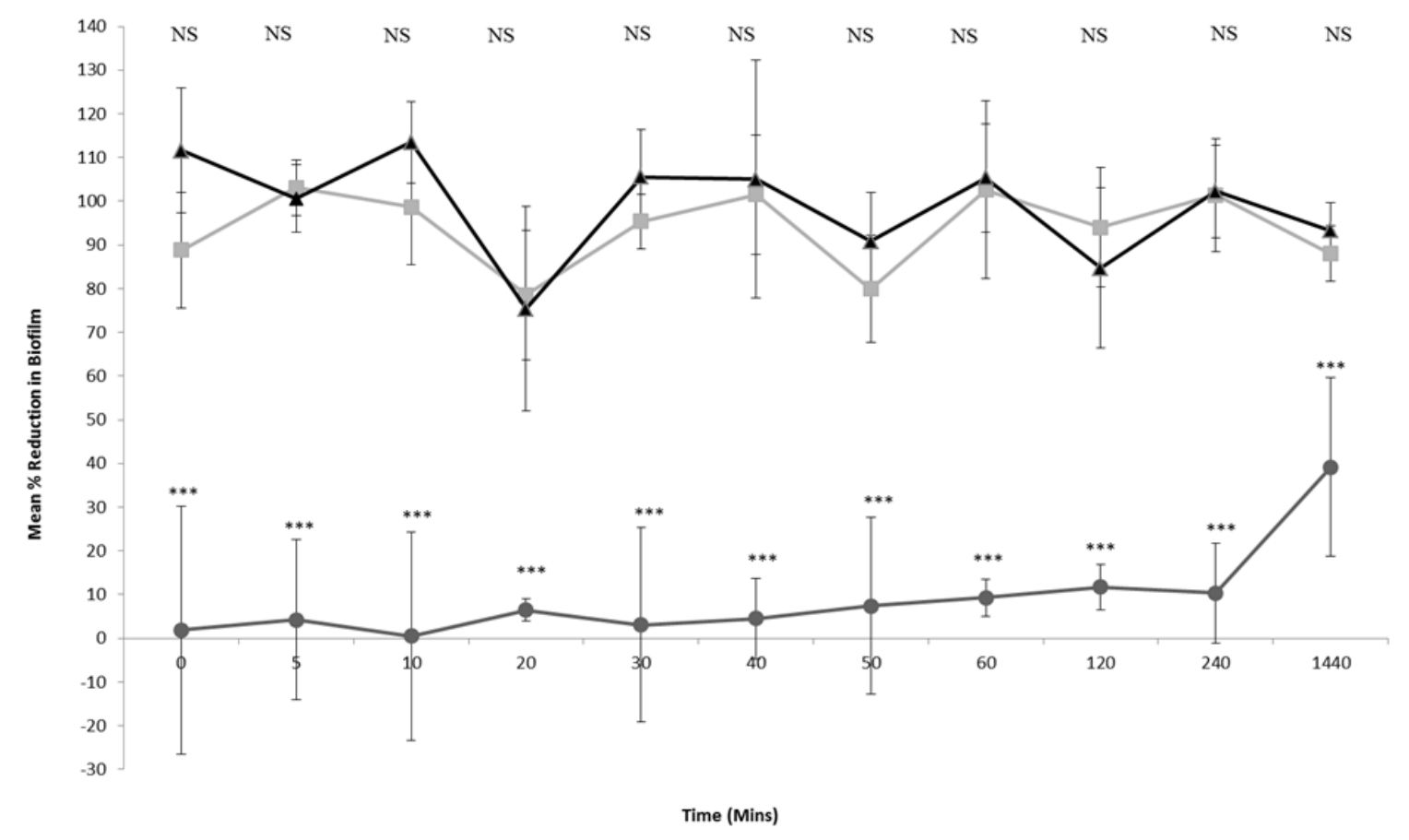

401

Fig. 1. Mean percentage reduction in 48 hour biofilm of Haemophilus actinomycetemcomitans (NCTC 10979) over a period of 24 hour exposure to food grade 0.125\%v/v ML:8 Emulsion, $0.12 \% \mathrm{v} / \mathrm{v}$ Chorhexidine digluconate and $2.4 \% \mathrm{v} / \mathrm{v}$ Virbac Vet Aquadent ${ }^{\circledR}$ utilising an alamarBlue ${ }^{\circledR}$ assay. Results are displayed as the mean of 8 replicates. Key: $\mathbf{n}: 0.12 \% \mathrm{v} / \mathrm{v}$ 
Chlorhexidine digluconate, $\triangle$ : 0.125\%v/v ML:8 Emulsion, •: 2.4\%v/v Virbac Vet Aquadent ${ }^{\circledR}$, ns: no significant difference $(\mathrm{P}>0.05) *$ : $\mathrm{P}<0.05$, **: $\mathrm{P}<0.01, * * *$ : $\mathrm{P}<0.001$, significant difference between efficacy of $0.125 \% \mathrm{v} / \mathrm{v}$ ML:8 Emulsion and 0.12\%v/v Chorhexidine digluconate or $2.4 \% \mathrm{v} / \mathrm{v}$ Virbac Vet Aquadent ${ }^{\circledR}$ at same timepoint.

410

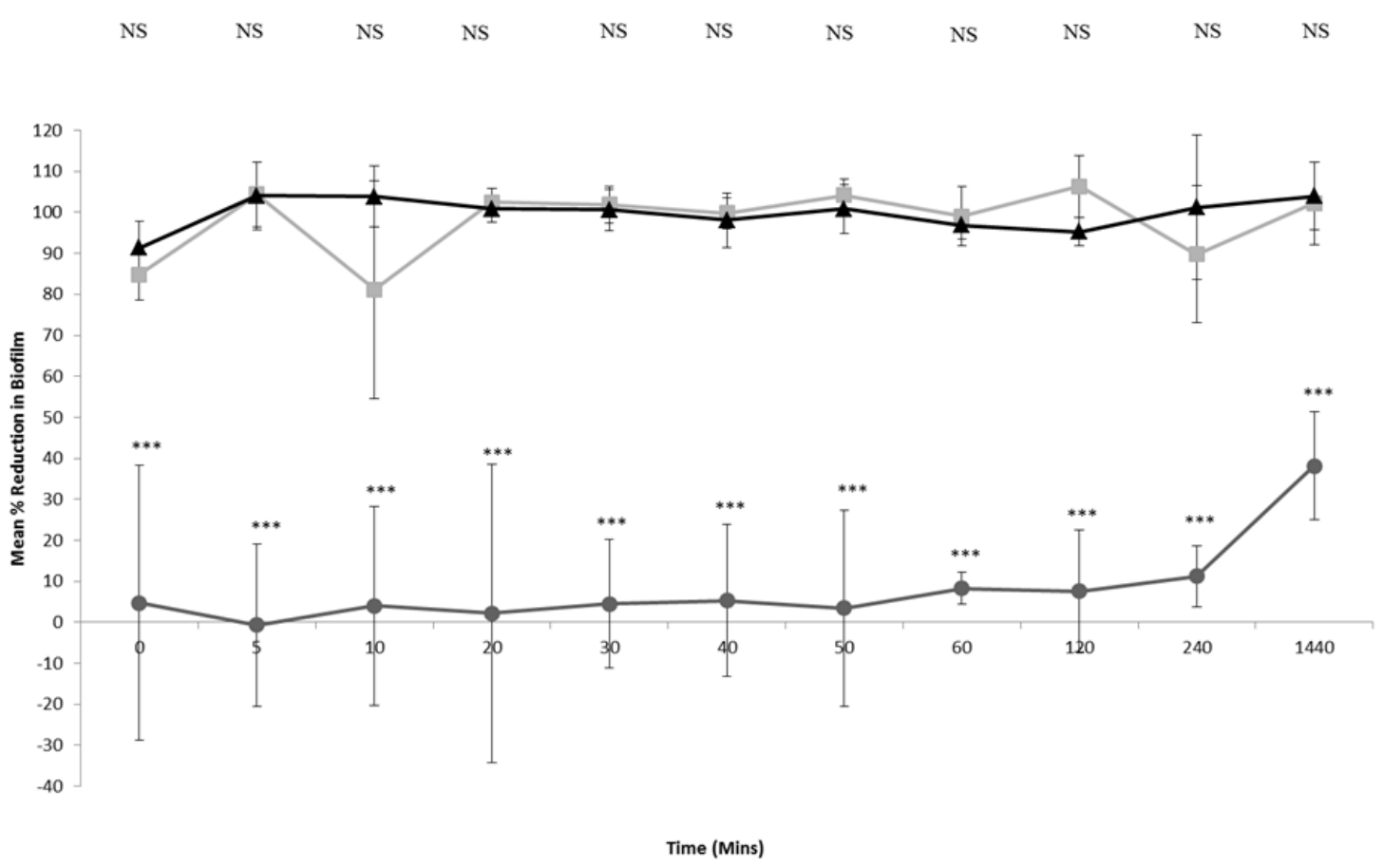

Fig. 2. Mean percentage reduction in 48 hour biofilm of Streptococcus sanguinis (NCTC 10904) over a period of 24 hour exposure to food grade 0.125\%v/v ML:8 Emulsion, 0.12\%v/v Chorhexidine digluconate and 2.4\%v/v Virbac Vet Aquadent ${ }^{\circledR}$ utilising an alamarBlue ${ }^{\circledR}$ assay. Results are displayed as the mean of 8 replicates. Key: $₫: 0.12 \% \mathrm{v} / \mathrm{v}$ Chlorhexidine digluconate, $\triangle$ : 0.125\%v/v ML:8 Emulsion, •: 2.4\%v/v Virbac Vet Aquadent ${ }^{\circledR}$, ns: no significant difference $(\mathbf{P}>0.05) *: \mathbf{P}<0.05, * *: \mathbf{P}<0.01, * * *: \mathbf{P}<0.001$, significant difference between efficacy of Aquadent ${ }^{\circledR}$ at same timepoint. 


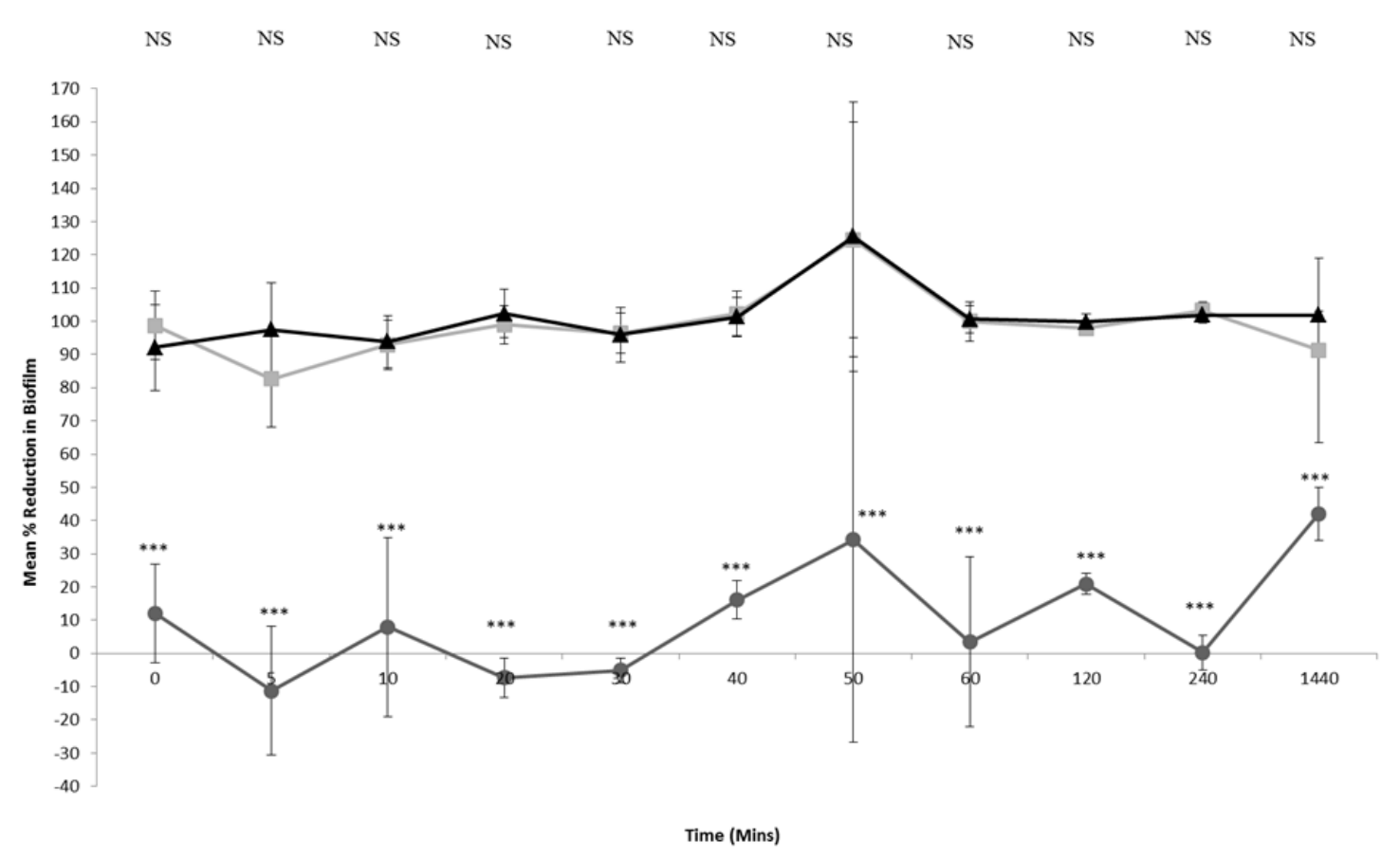

425 Fig. 3. Mean percentage reduction in 48 hour biofilm of Porphyromonas cangingivalis (VPB 4874) over a period of 24 hour exposure to food grade $0.125 \% \mathrm{v} / \mathrm{v}$ ML:8 Emulsion, $0.12 \% \mathrm{v} / \mathrm{v}$ Chorhexidine digluconate and $2.4 \% \mathrm{v} / \mathrm{v}$ Virbac Vet Aquadent ${ }^{\circledR}$ utilising an alamarBlue ${ }^{\circledR}$ assay. Results are displayed as the mean of 8 replicates. Key: $\approx: 0.12 \% \mathrm{v} / \mathrm{v}$ Chlorhexidine digluconate, $\triangle$ : 0.125\%v/v ML:8 Emulsion, •: 2.4\%v/v Virbac Vet Aquadent ${ }^{\circledR}$, ns: no significant difference $(\mathbf{P}>0.05) *: \mathbf{P}<0.05, * *: \mathbf{P}<0.01, * * *: \mathbf{P}<0.001$, significant difference between efficacy of 0.125\%v/v ML:8 Emulsion and 0.12\%v/v Chorhexidine digluconate or 2.4\%v/v Virbac Vet Aquadent ${ }^{\circledR}$ at same timepoint. 


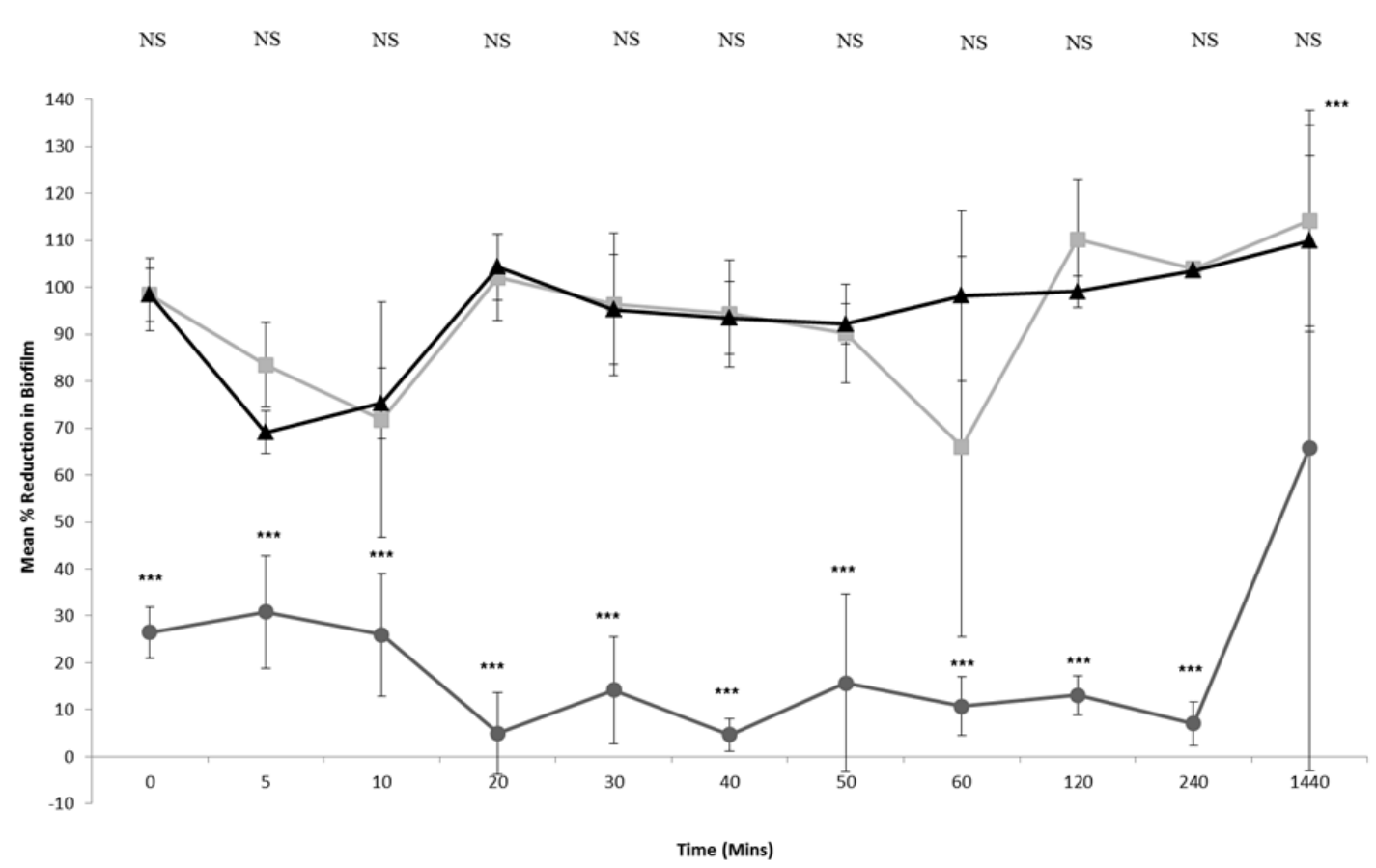

439 Fig. 4. Mean percentage reduction in 48 hour biofilm of Porphyromonas salivosa (VPB 3313)

440 over a period of 24 hour exposure to food grade 0.125\%v/v ML:8 Emulsion, 0.12\%v/v

441 Chorhexidine digluconate and $2.4 \%$ v/v Virbac Vet Aquadent ${ }^{\circledR}$ utilising an alamarBlue ${ }^{\circledR}$ assay.

442 Results are displayed as the mean of 8 replicates. Key: $\mathbf{m}: 0.12 \% \mathrm{v} / \mathrm{v}$ Chlorhexidine digluconate,

$443 \Delta$ : 0.125\%v/v ML:8 Emulsion, •: 2.4\%v/v Virbac Vet Aquadent ${ }^{\circledR}$, ns: no significant difference

$444(\mathbf{P}>\mathbf{0 . 0 5}) *: \mathbf{P}<\mathbf{0 . 0 5}, * *: \mathbf{P}<\mathbf{0 . 0 1}, * * *: \mathbf{P}<\mathbf{0 . 0 0 1}$, significant difference between efficacy of

$445 \quad 0.125 \% \mathrm{v} / \mathrm{v}$ ML:8 Emulsion and 0.12\%v/v Chorhexidine digluconate or 2.4\%v/v Virbac Vet

446 Aquadent ${ }^{\circledR}$ at same timepoint. 


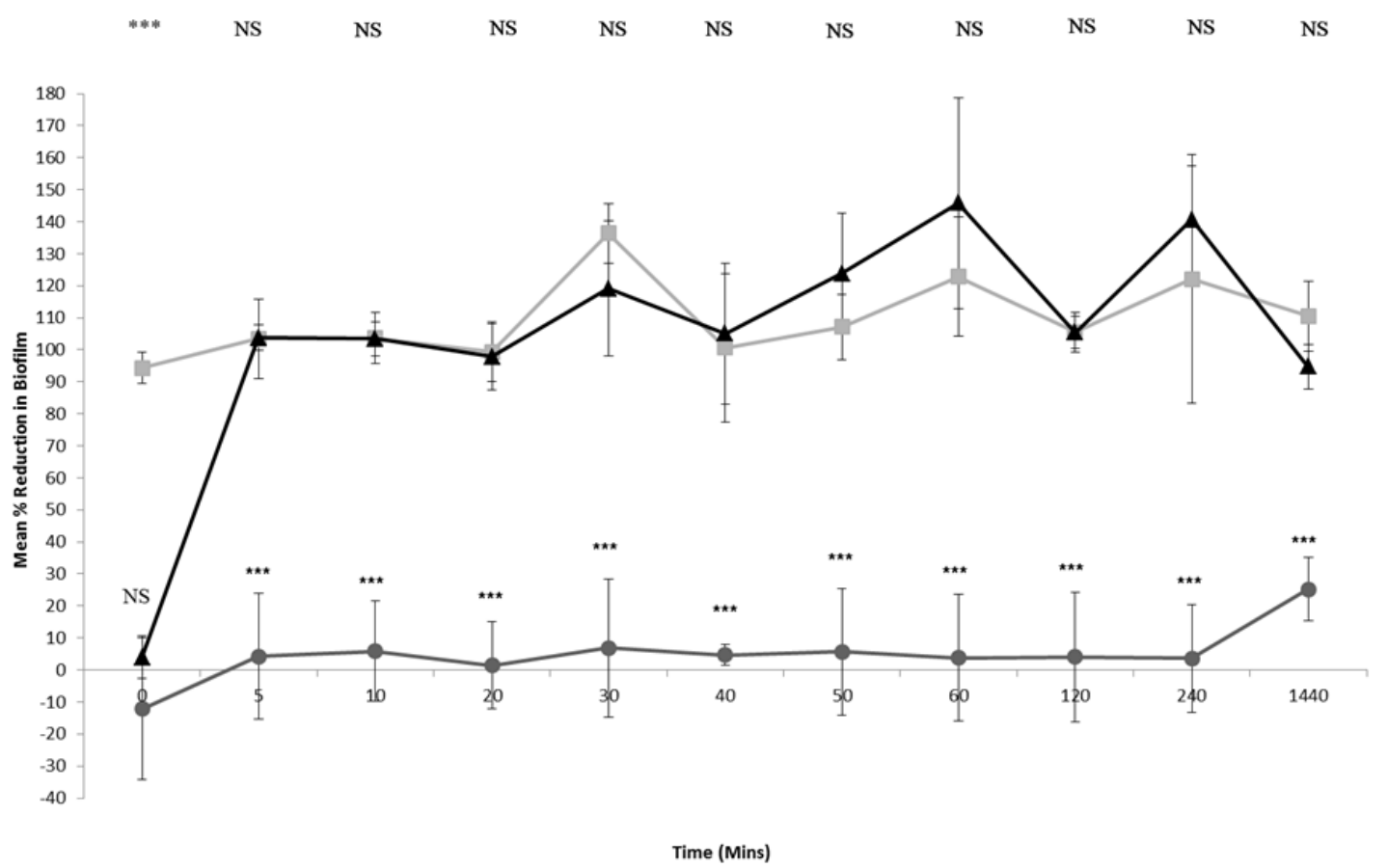

449 Fig. 5. Mean percentage reduction in 48 hour biofilm of Porphyromonas gingivalis (VPB 5089)

450 over a period of 24 hour exposure to food grade $0.125 \% \mathrm{v} / \mathrm{v}$ ML:8 Emulsion, $0.12 \% \mathrm{v} / \mathrm{v}$

451 Chorhexidine digluconate and 2.4\%v/v Virbac Vet Aquadent ${ }^{\circledR}$ utilising an alamarBlue ${ }^{\circledR}$ assay.

452 Results are displayed as the mean of 8 replicates. Key: $\mathbf{~}: 0.12 \% \mathrm{v} / \mathrm{v}$ Chlorhexidine digluconate,

$453 \triangle \Delta: 0.125 \% \mathrm{v} / \mathrm{v}$ ML:8 Emulsion, •: 2.4\%v/v Virbac Vet Aquadent ${ }^{\circledR}$, ns: no significant difference

$454 \quad(\mathbf{P}>\mathbf{0 . 0 5}) *: \mathbf{P}<\mathbf{0 . 0 5},{ }^{* *}: \mathbf{P}<\mathbf{0 . 0 1},{ }^{* * *}: \mathbf{P}<\mathbf{0 . 0 0 1}$, significant difference between efficacy of

$455 \quad 0.125 \% \mathrm{v} / \mathrm{v}$ ML:8 Emulsion and 0.12\%v/v Chorhexidine digluconate or 2.4\%v/v Virbac Vet

456 Aquadent ${ }^{\circledR}$ at same timepoint. 


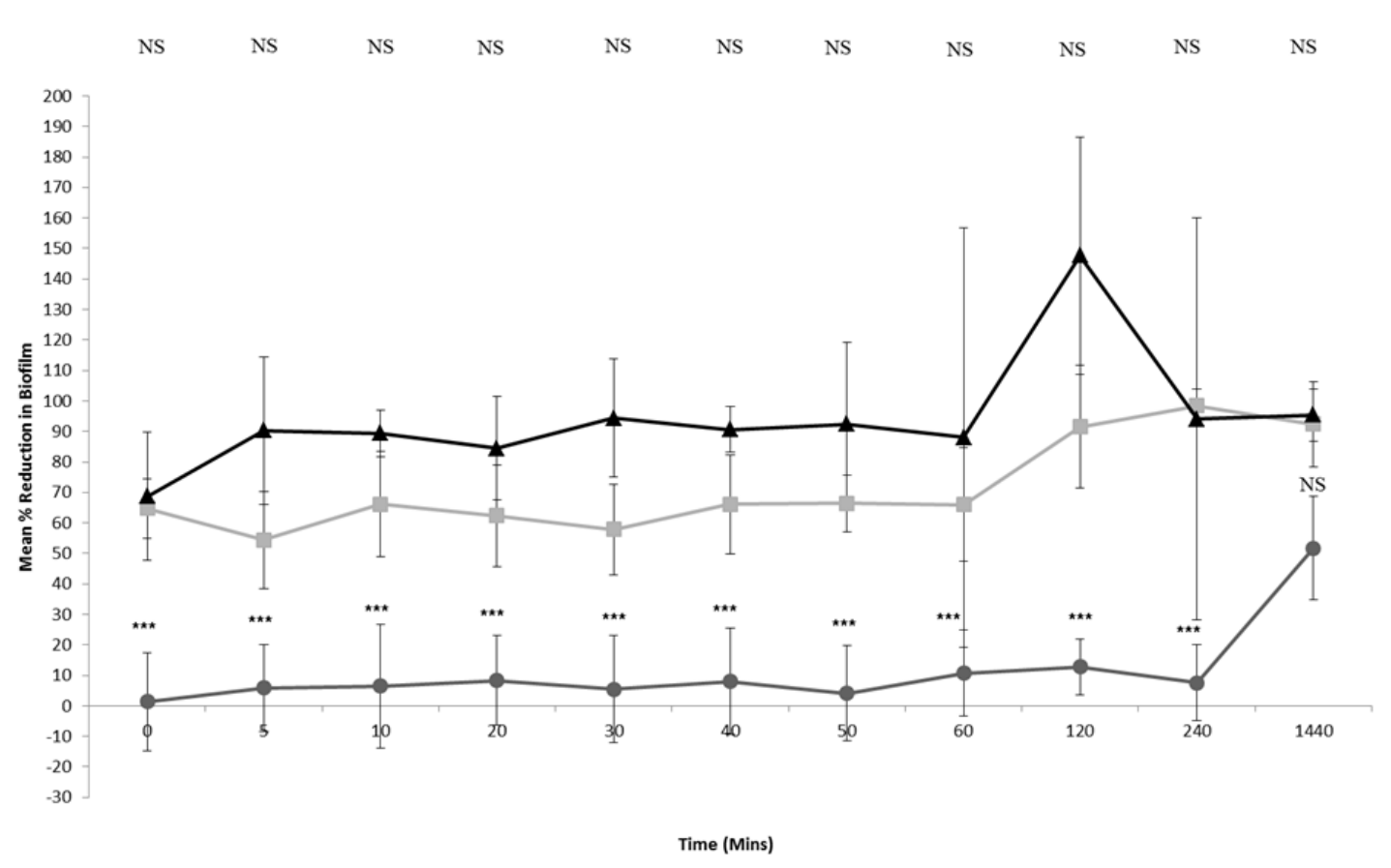

459 Fig. 6. Mean percentage reduction in 48 hour biofilm of Fusobacterium nucleatum (VPB 4888) 460 over a period of 24 hour exposure to food grade 0.125\%v/v ML:8 Emulsion, 0.12\%v/v 461 Chorhexidine digluconate and $2.4 \% \mathrm{v} / \mathrm{v}$ Virbac Vet Aquadent ${ }^{\circledR}$ utilising an alamarBlue ${ }^{\circledR}$ assay. 462 Results are displayed as the mean of 8 replicates. Key: $\mathbf{m}: 0.12 \% \mathrm{v} / \mathrm{v}$ Chlorhexidine digluconate, $463 \Delta$ : $0.125 \% \mathrm{v} / \mathrm{v}$ ML:8 Emulsion, •: 2.4\%v/v Virbac Vet Aquadent ${ }^{\circledR}$, ns: no significant difference 464 (P>0.05) *: $\mathbf{P}<0.05, * *: P<0.01, * * *: P<0.001$, significant difference between efficacy of 0.125\%v/v ML:8 Emulsion and 0.12\%v/v Chorhexidine digluconate or 2.4\%v/v Virbac Vet Aquadent ${ }^{\circledR}$ at same timepoint. 


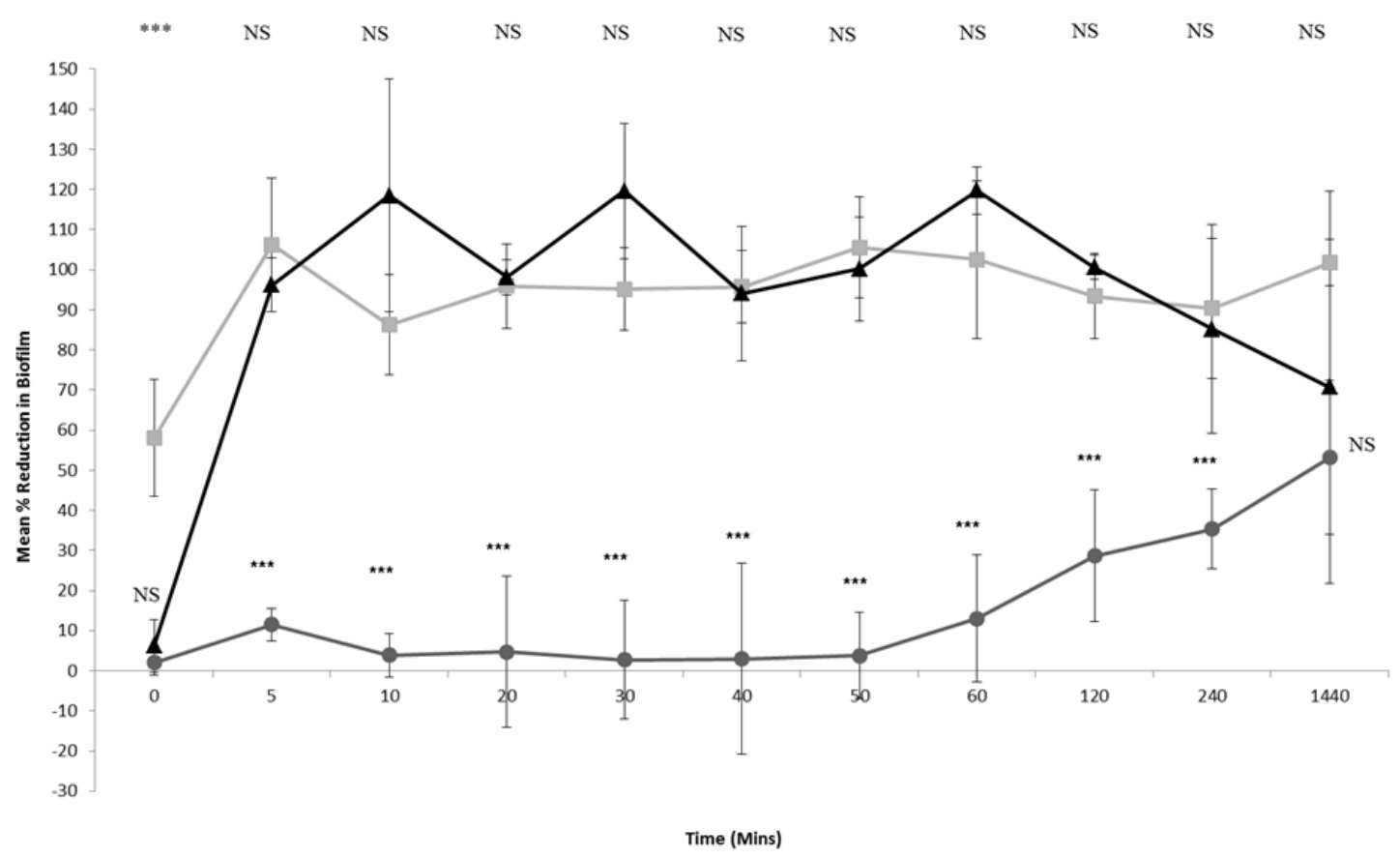

468 Fig. 7. Mean percentage reduction in 48 hour biofilm of Eikenella corrodens (VPB 3935) over a 469 period of 24 hour exposure to food grade 0.125\%v/v ML:8 Emulsion, 0.12\%v/v Chorhexidine 470 digluconate and $2.4 \% \mathrm{v} / \mathrm{v}$ Virbac Vet Aquadent ${ }^{\circledR}$ utilising an alamarBlue ${ }^{\circledR}$ assay. Results are 471 displayed as the mean of 8 replicates. Key: $\mathbf{m : 0 . 1 2 \% v / v ~ C h l o r h e x i d i n e ~ d i g l u c o n a t e , ~} \Delta$ :

$4720.125 \% \mathrm{v} / \mathrm{v}$ ML:8 Emulsion, $\bullet: 2.4 \% \mathrm{v} / \mathrm{v}$ Virbac Vet Aquadent ${ }^{\circledR}$, ns: no significant difference $473 \quad(\mathbf{P}>\mathbf{0 . 0 5}) *: \mathbf{P}<\mathbf{0 . 0 5},{ }^{* *}: \mathbf{P}<\mathbf{0 . 0 1}, * * *: \mathbf{P}<\mathbf{0 . 0 0 1}$, significant difference between efficacy of 0.125\%v/v ML:8 Emulsion and 0.12\%v/v Chorhexidine digluconate or 2.4\%v/v Virbac Vet 475 Aquadent ${ }^{\circledR}$ at same timepoint. 


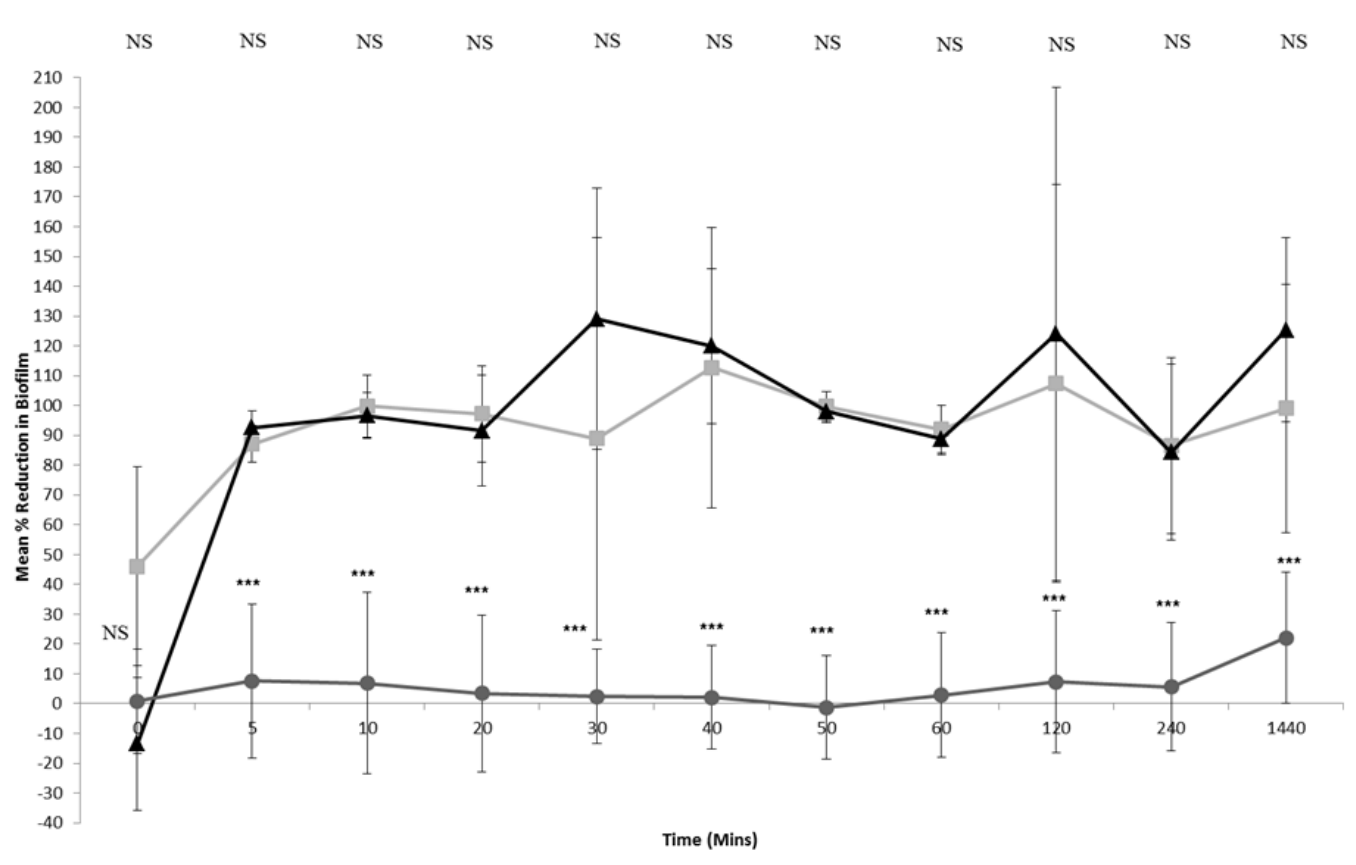

478 Fig. 8. Mean percentage reduction in 48 hour biofilm of Bacteroides fragilis (VPB 3371) over a 479 period of 24 hour exposure to food grade 0.125\%v/v ML:8 Emulsion, 0.12\%v/v Chorhexidine 480 digluconate and $2.4 \% \mathrm{v} / \mathrm{v}$ Virbac Vet Aquadent ${ }^{\circledR}$ utilising an alamarBlue ${ }^{\circledR}$ assay. Results are 481 displayed as the mean of 8 replicates. Key: $\mathbf{m}: \mathbf{0 . 1 2} \% \mathrm{v} / \mathrm{v}$ Chlorhexidine digluconate, $\Delta$ : 0.125\%v/v ML:8 Emulsion, $\bullet: 2.4 \% \mathrm{v} / \mathrm{v}$ Virbac Vet Aquadent ${ }^{\circledR}$, ns: no significant difference $(\mathbf{P}>0.05) *: \mathbf{P}<0.05, * *: \mathbf{P}<0.01, * * *: \mathbf{P}<0.001$, significant difference between efficacy of 0.125\%v/v ML:8 Emulsion and 0.12\%v/v Chorhexidine digluconate or 2.4\%v/v Virbac Vet Aquadent ${ }^{\circledR}$ at same timepoint. 


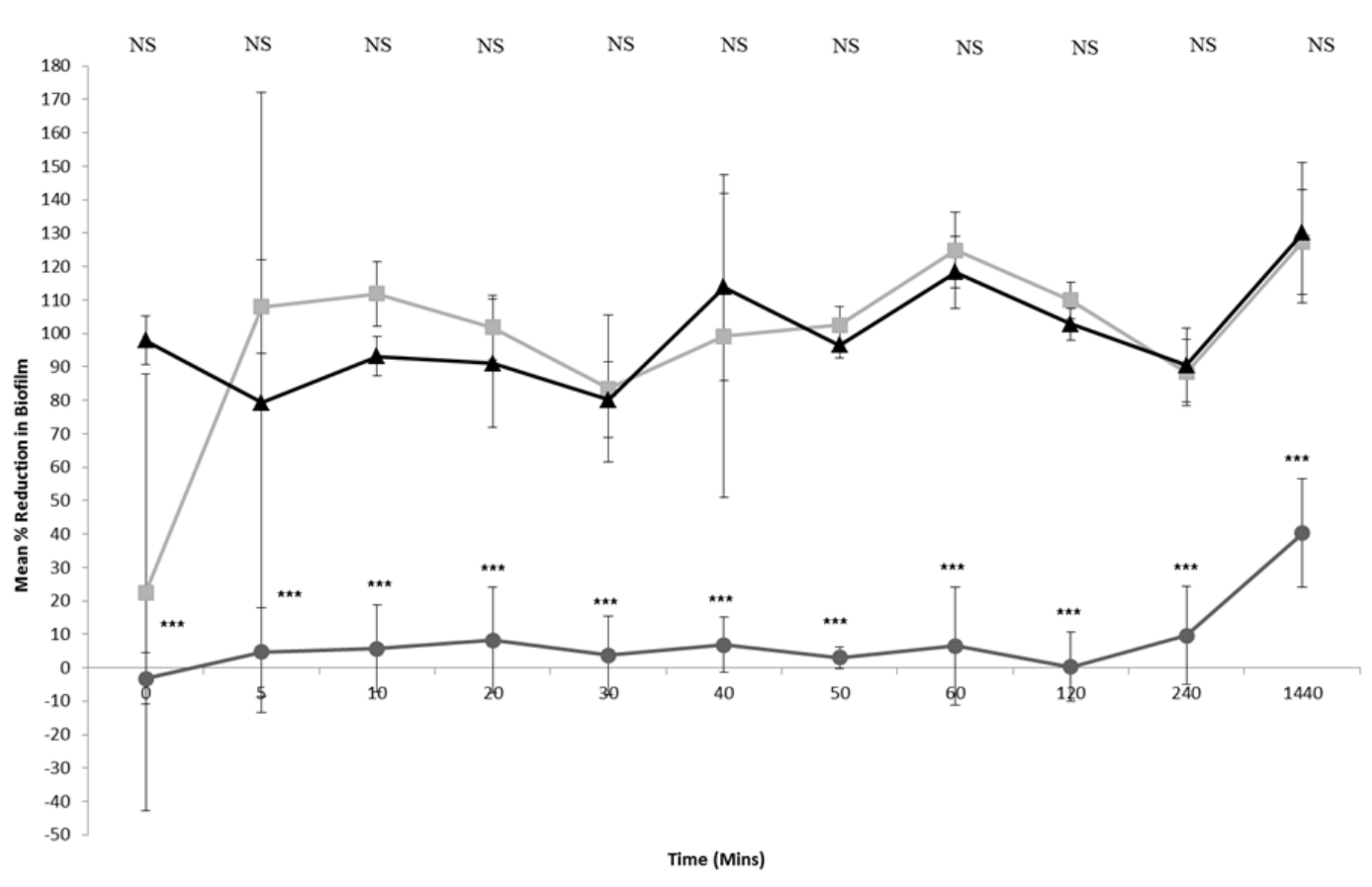

486

487 Fig. 9. Mean percentage reduction in 48 hour biofilm of Prevotella intermedia (VPB 3321) over a 488 period of 24 hour exposure to food grade 0.125\%v/v ML:8 Emulsion, 0.12\%v/v Chorhexidine 489 digluconate and $2.4 \% \mathrm{v} / \mathrm{v}$ Virbac Vet Aquadent ${ }^{\circledR}$ utilising an alamarBlue ${ }^{\circledR}$ assay. Results are 490 displayed as the mean of 8 replicates. Key: $\mathbf{m :} 0.12 \% \mathrm{v} / \mathrm{v}$ Chlorhexidine digluconate, $\Delta$ :

$491 \quad 0.125 \% \mathrm{v} / \mathrm{v}$ ML:8 Emulsion, $\bullet: 2.4 \% \mathrm{v} / \mathrm{v}$ Virbac Vet Aquadent ${ }^{\circledR}$, ns: no significant difference $492 \quad(\mathbf{P}>\mathbf{0 . 0 5}) *: \mathbf{P}<\mathbf{0 . 0 5}, * *: \mathbf{P}<\mathbf{0 . 0 1}, * * *: \mathbf{P}<\mathbf{0 . 0 0 1}$, significant difference between efficacy of $493 \quad 0.125 \%$ v/v ML:8 Emulsion and 0.12\%v/v Chorhexidine digluconate or 2.4\%v/v Virbac Vet 494 Aquadent ${ }^{\circledR}$ at same timepoint. 


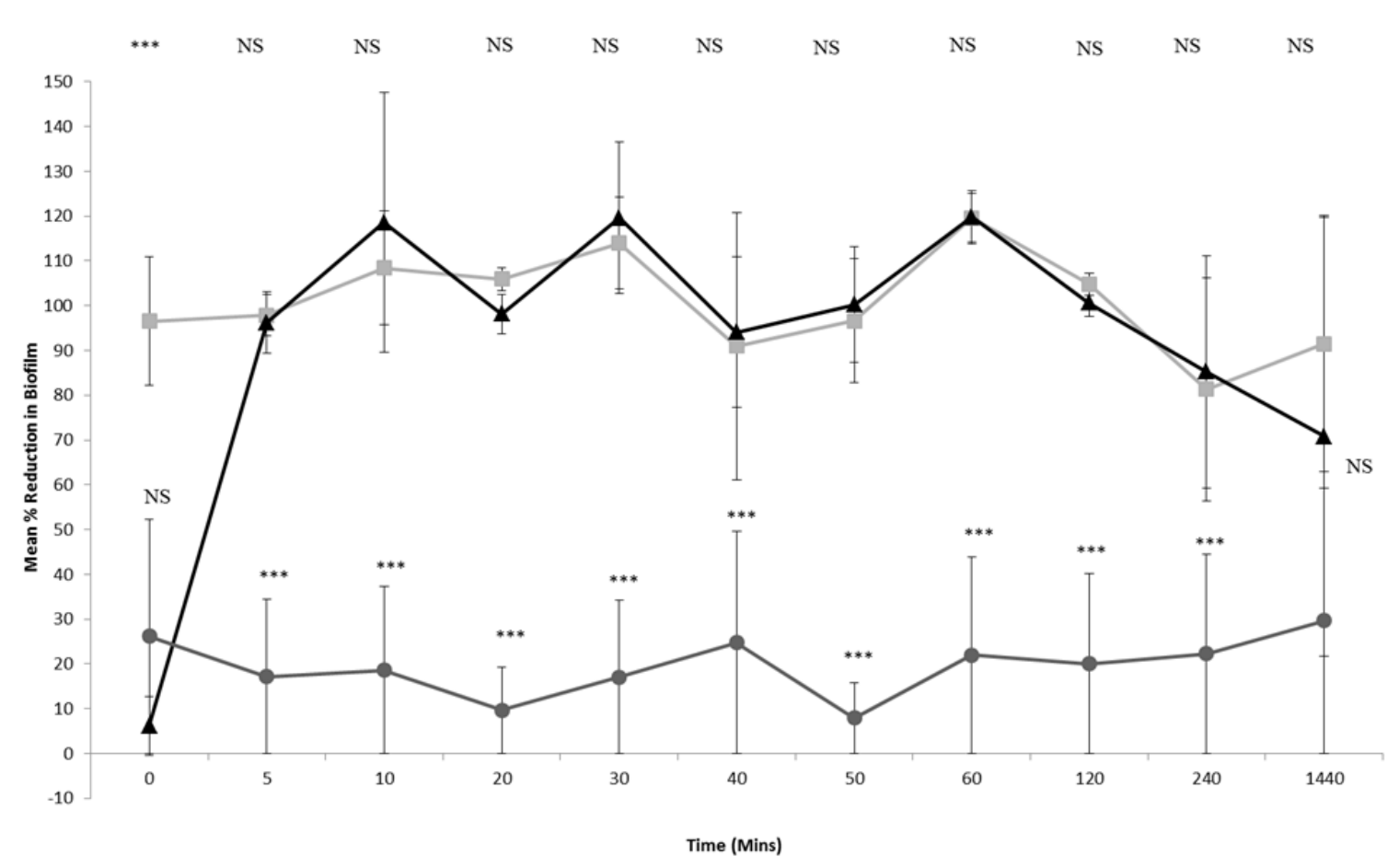

497 Fig. 10. Mean percentage reduction in 48 hour biofilm of Tanerrella forsythesis (VPB 4947) over a period of 24 hour exposure to food grade 0.125\%v/v ML:8 Emulsion, 0.12\%v/v Chorhexidine digluconate and 2.4\%v/v Virbac Vet Aquadent ${ }^{\circledR}$ utilising an alamarBlue ${ }^{\circledR}$ assay. Results are

500 displayed as the mean of 8 replicates. Key: $n: 0.12 \% \mathrm{v} / \mathrm{v}$ Chlorhexidine digluconate, $\Delta$ : 0.125\%v/v ML:8 Emulsion, •: 2.4\%v/v Virbac Vet Aquadent ${ }^{\circledR}$, ns: no significant difference $(\mathbf{P}>0.05) *: \mathbf{P}<0.05, * *: \mathbf{P}<0.01, * * *: \mathbf{P}<0.001$, significant difference between efficacy of 0.125\%v/v ML:8 Emulsion and 0.12\%v/v Chorhexidine digluconate or 2.4\%v/v Virbac Vet Aquadent ${ }^{\circledR}$ at same timepoint. 


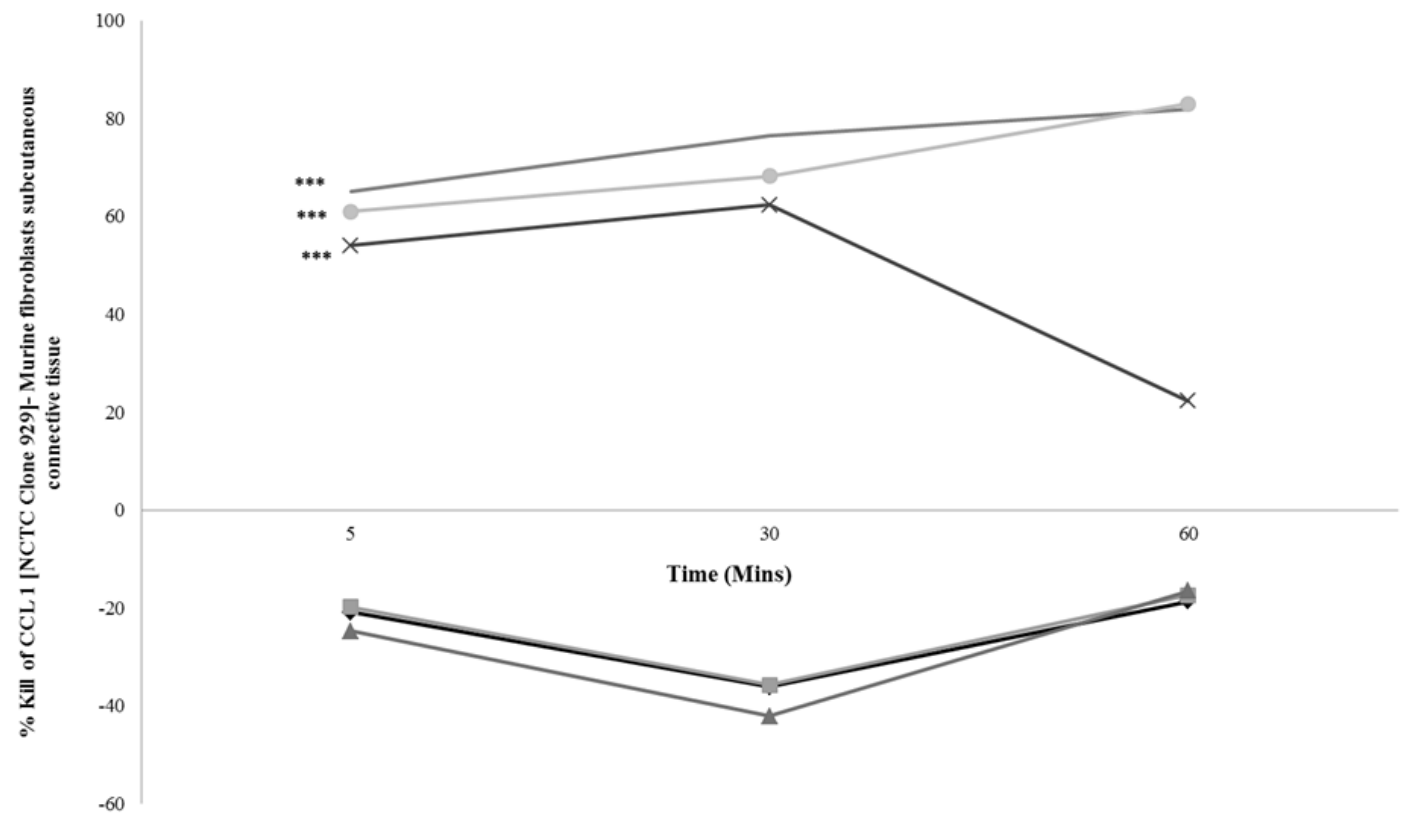

509 Fig. 11. The percentage kill of CCL 1 [NCTC clone 929]- murine fibroblasts subcutaneous

510 connective tissue monolayer cells after $\mathbf{5 , 3 0}$ and 60 minutes exposure to varying concentrations

511 of ML:8 emulsion and Chlorhexidine digluconate (CHX). Results are obtained via the use of an

512 alamarBlue ${ }^{\circledR}$ assay (10 hour development time). Key:

$-0.25 \% \mathrm{v} / \mathrm{v}$ ML: 8

513 $\leftarrow 0.25 \% \mathrm{v} / \mathrm{v} \mathrm{CHX}$

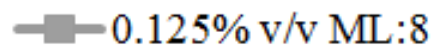

$0.125 \% \mathrm{v} / \mathrm{v} \mathrm{CHX}$
$-0.0625 \% \mathrm{v} / \mathrm{v} \mathrm{ML}: 8$

$-0.0625 \% \mathrm{v} / \mathrm{v} \mathrm{CHX}$

514 ns: no significant difference $(\mathbf{P}>\mathbf{0 . 0 5}),{ }^{*}: \mathbf{P}<\mathbf{0 . 0 5},{ }^{* *}: \mathbf{P}<\mathbf{0 . 0 1}, * * *: \mathbf{P}<\mathbf{0 . 0 0 1}$, significant difference

515 between cytotoxicity of ML:8 Emulsion and Chorhexidine digluconate at same time point and

516 concentration. 


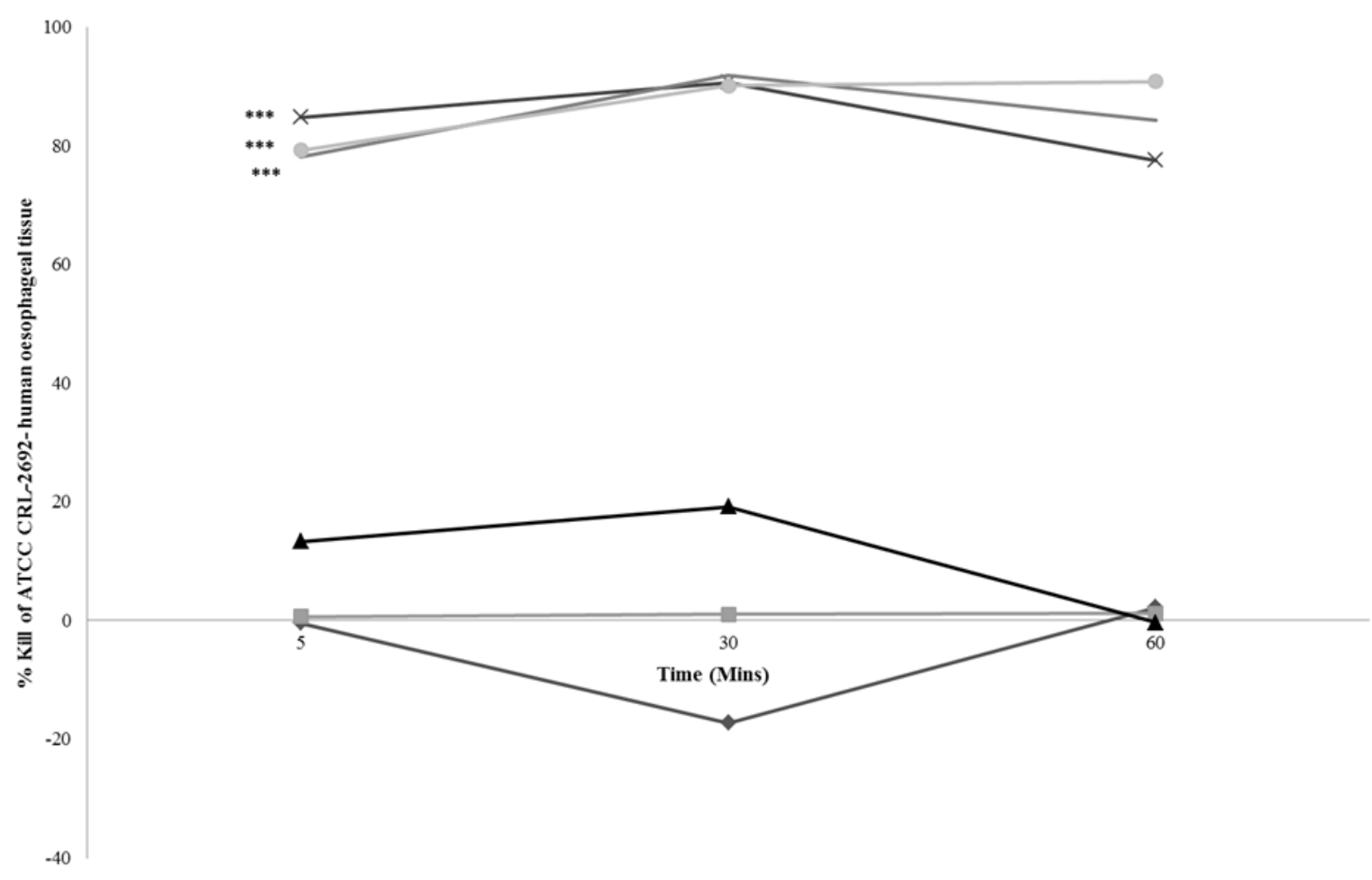

518 Fig. 12. The percentage kill of ATCC CRL-2692- human oesophageal tissue monolayer cells

519 after 5, 30 and 60 minutes exposure to varying concentrations of ML:8 emulsion and

520 Chlorhexidine digluconate (CHX). Results are obtained via the use of an alamarBlue ${ }^{\circledR}$ assay (10

521 hour development time). Key:

$-0.25 \% \mathrm{v} / \mathrm{v} \mathrm{ML}: 8$

522

523

524

525

526

527

528

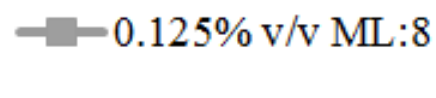

$0.125 \% \mathrm{v} / \mathrm{v}$ CHX concentration.
$-0.0625 \% \mathrm{v} / \mathrm{v} \mathrm{ML}: 8$

$0.0625 \% \mathrm{v} / \mathrm{v} \mathrm{CHX}$

ns: no significant difference (P>0.05), ${ }^{*}: \mathbf{P}<0.05, * *: P<0.01, * * *: P<0.001$, significant difference between cytotoxicity of ML:8 Emulsion and Chorhexidine digluconate at same time point and 